\title{
Bovine stomach myosin light chain kinase with a marked discrepancy between its enzyme activity and actomyosin activating effect
}

\author{
By Setsuro Ebashi, M. J. A., ${ }^{*)}$ Hideto Kuwayama, ${ }^{* *}$ and Chizue Nanko*) \\ (Communicated June 23, 1998)
}

\begin{abstract}
An attempt was made to confirm and develop the work of Kuwayama et al. (J. Biochem. 104, 862-866, 1988) which showed a significant discrepancy between myosin light chain kinase (MLCK) activity (Kactivity) and actomyosin-activating activity (L-activity) of bovine stomach. A simple method of preparing 155 $\mathrm{kDa}$ protein identical with MLCK was presented. Preparations thus obtained showed high ratios of the Lactivity to the K-activity, the highest being 230 . This indicates that a mechanism other than the phosphorylation of light chain plays a crucial role on the molecular level in activating contractile processes of the actomyosin-ATP system.
\end{abstract}

Key words : Myosin light chain kinase; actomyosin-activating activity; $155 \mathrm{kDa}$ protein; dual function; leiotonin.

Kuwayama et al. ${ }^{1)}$ isolated from bovine aorta two kinds of myosin light chain kinase (MLCK) of different molecular weights, $155 \mathrm{kDa}$ and $130 \mathrm{kDa}$, respectively. The former showed an actomyosin-activating activity 5 times higher than the latter on the basis of equivalent MLCK activity. They then applied the same procedure to bovine stomach and found an even more marked discrepancy between the two activities, i.e., 10 times or more.

Prior to this finding, several procedures were found to preferentially repress either of these two activities. ${ }^{2)}$ This was at variance with the contemporary concept that smooth muscle contraction depends primarily on the phosphorylation of regulatory light chain of myosin (MLC), but since the MLCK preparations used in these reports were in a crude state, most researchers who firmly believed in the MLCK concept did not take them seriously, feeling sure that some other factor(s) included in crude preparations must be responsible for these unexplainable results. This kind of argument, however, is no longer applicable to the work done by Kuwayama et al.,${ }^{1)}$ because the MLCK used in that work was almost homogeneous.

Under these circumstances, it is a natural course of subsequent research to attempt to eliminate the remaining

*) National Institute for Physiological Sciences, Myodaiji, Okazaki 444-8585, Japan. Mailing Address: Nagaizumi 17-503, Myodaiji, Okazaki 444-0864, Japan.

**) Laboratory of Chemistry, Obihiro University of Agriculture and Veterinary Medicine, Hokkaido 080-0856, Japan. kinase activity of the $155 \mathrm{kDa}$ component as much as possible, while keeping its actomyosin-activating action intact.

Materials and methods. Materials. Bovine stomach was used as the source of active principles. Fresh material from a slaughterhouse was minced with a mincer, which had a hole about $3 \mathrm{~mm}$ in diameter. Minced meat was usually used immediately for the preparation of factors, but mince which had been frozen at $-80^{\circ} \mathrm{C}$ was also used in some experiments.

Assay of biological activities. Actomyosin-activating activity was assayed by the superprecipitation method. ${ }^{1)}$ Desensitized bovine myosin B, or desensitized natural actomyosin, ${ }^{1,4)}$ was used as the testing material. ${ }^{1,3)}$

Superprecipitation was carried out as previously described. ${ }^{1)}$ The reaction mixture, $2 \mathrm{ml}$ in total, was composed of $0.02 \mathrm{M} \mathrm{KCl}, 8 \mathrm{mM} \mathrm{MgCl}_{2}, 0.02 \mathrm{M}$ imidazole (pH 6.8), 0.05-0.07 mg desensitized myosin B (kept in 0.6 $\mathrm{M} \mathrm{NaCl}$ before use), $2 \mu \mathrm{g}$ calmodulin, $10 \mu \mathrm{g}$ gizzard tropomyosin, $1 \mathrm{mM}$ Ca-EGTA buffer $\left(13 \mu \mathrm{M} \mathrm{Ca}^{2+}\right)$ and $0.5 \mathrm{mM}$ ATP. The reaction was started by adding $0.1 \mathrm{ml}$ of $20 \mathrm{mM}$ ATP to the mixture. All reactions were carried out at room temperature, i.e., $23-25^{\circ} \mathrm{C}$.

MLCK activity was determined by the method of Pires and Perry ${ }^{3)}$ with some modification. The reaction mixture, $0.1 \mathrm{ml}$ in total, was composed of $0.01 \mathrm{M} \mathrm{KCl}, 8$ $\mathrm{mM} \mathrm{MgCl} 2,0.02 \mathrm{M}$ imidazole buffer ( $\mathrm{pH} 6.8$ ), $0.5 \mu \mathrm{g}$ calmodulin, $0.04 \mathrm{mg}$ myosin, $1 \mathrm{mM}$ Ca-EGTA buffer (13 $\mu \mathrm{M} \mathrm{Ca}^{2+}$ ) (dissolved in $0.3 \mathrm{M} \mathrm{NaCl}$ ) and $0.2 \mathrm{mM}$ ATP. 


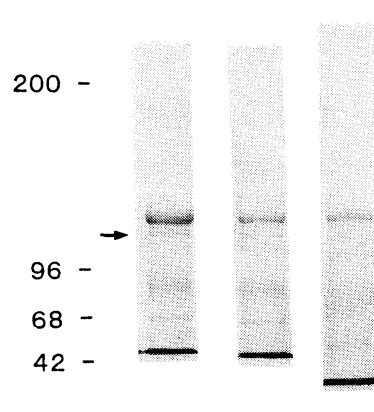

$20 \mathrm{Mg}$

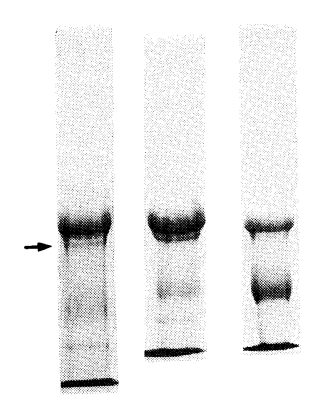

AS

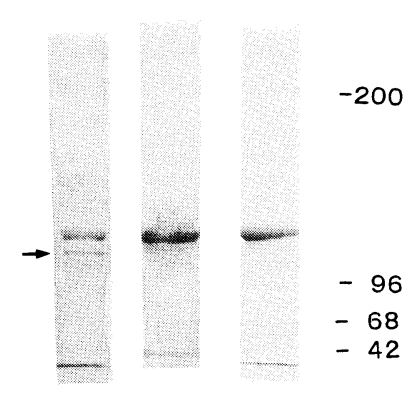

Gel-fil

Fig. 1. SDS gel-electrophoretic patterns at different steps of purification of bovine stomach 155 $\mathrm{kDa}$ component. $20 \mathrm{Mg}$ : extracts with $20 \mathrm{mM} \mathrm{Mg}$. AS: precipitates by ammonium sulfate between 24 and $28 \mathrm{~g}$ per $100 \mathrm{ml}$. Gel-fil: gel-filtered sample. Molecular markers on left and right sides correspond to the longest and shortest lanes, respectively. Their $\mathrm{L} / \mathrm{K}$ ratios are listed in Table I.

Reactions were begun by adding $1 \mu$ of $20 \mathrm{mM}$ ATP. The mixture was incubated at $25^{\circ} \mathrm{C}$ for $5 \mathrm{~min}$ and after the reaction was completed by adding $100 \mathrm{mg}$ of urea, its supernate was subjected to gel-electrophoresis. To measure the degree of phosphorylation of superprecipitating actomyosin, the reaction was terminated by adding an equal amount of methanol, and after centrifugation the sediment was mixed with $100 \mathrm{mg}$ urea and treated as above.

Standardization of activities. In the previous paper the ratio of L-activity to $\mathrm{K}$-activity, $\mathrm{L} / \mathrm{K}$, was calculated comparing the activities of samples in a series ${ }^{1)}$ (Fig. 5 in ref. 1). To generalize $\mathrm{L} / \mathrm{K}$ of different samples, both activities were expressed relative to those of the standard sample, taking the activity of the standard as one unit. The standard was prepared in the following way.

The first extract derived from $100 \mathrm{~g}$ of mince (see Results) was subjected to ammonium sulfate fractionation, and the precipitates between $25 \mathrm{~g}$ and $40 \mathrm{~g}$ of ammonium sulfate per $100 \mathrm{ml}$ were dissolved in $50 \mathrm{ml}$ of water and centrifuged. The resulting clear supernatant was used as the standard. Storage at $-80^{\circ} \mathrm{C}$ caused no change in its activities; even at $-25^{\circ} \mathrm{C}$, there was virtually no decrease over a several month period.

Results. Preparation of $155 \mathrm{kDa}$ component with low MLCK activity. All solutions used for the preparation of the component contained $3 \times 10 \mu \mathrm{M}$ leupeptin. ${ }^{* 2)}$ One hundred grams of muscle mince was immersed in 4 volumes of water and mixed well. After $1 \mathrm{hr}$ the mixture was centrifuged at 11,000 r.p.m. (effective diameter of the rotor, $11 \mathrm{~cm}$ ) for $10 \mathrm{~min}$ and the resulting residue (its supernatant was used as the material for preparing the standard as described above) was subjected to the same procedure as above, making the total volume of the suspension $500 \mathrm{ml}$. This procedure was repeated two additional times. During these processes, the mince swelled to twice or more its original volume.

To this swollen mince $1 \mathrm{M} \mathrm{MgCl}_{2}$ was added up to $20 \mathrm{mM}$ in its final concentration and thoroughly mixed. After $2 \mathrm{hr}$ the suspension was centrifuged as above. The mince shrank considerably, resulting in a relatively large amount about $120 \mathrm{ml}$ of supernatant. The residue was mixed well with $100 \mathrm{ml}$ of $20 \mathrm{mM} \mathrm{MgCl}_{2}$ and after several $\mathrm{hr}$, suspension was centrifuged in the same way as above; almost the same amount of supernatant was obtained as the first time.

To the $100 \mathrm{ml}$ of the combined Mg-extract, $24 \mathrm{~g}$ of ammonium sulfate was added and to the clear supernatant after centrifugation $4 \mathrm{~g}$ ammonium sulfate was also added. Two hr later, the resulting precipitates collected by centrifugation were thoroughly suspended in a minimum amount of water, $1 \mathrm{ml}$ or less, and the insoluble portion was removed by centrifugation. The clear supernatant was then subjected to gel-filtration using TSK gel G 4000SWXL incorporated into HPLC.

SDS gel-electrophoretic patterns of the sample during the purification process are shown in the figure (Fig. 1).

*2) This is a crucial point of preparing $155 \mathrm{kDa}$ component. As reported, an appropriate concentration of trypsin and some proteases preferentially destroy the L-activity. ${ }^{2)}$ Indeed, the preparation made without protease inhibitor often shows a L-activity lower than that with the inhibitor, whereas virtually no change in its K-activity. 
Table I. L/K ratios of $155 \mathrm{kDa}$ proteins at each step of purification

\begin{tabular}{cc}
\hline Step & $\begin{array}{c}\text { L/K ratios } \\
\text { (averages) }\end{array}$ \\
\hline $\begin{array}{c}\text { Extraction with } \\
20 \mathrm{mM} \mathrm{Mg}\end{array}$ & $\begin{array}{c}18,20 \\
(15)\end{array}$ \\
\hline $\begin{array}{c}\text { Ammonium sulfate } \\
\text { fractionation }\end{array}$ & $\begin{array}{c}45, \\
(94)\end{array}$ \\
\hline Gel-filtration & $82, \begin{array}{c}230,144 \\
(152)\end{array}$ \\
\hline
\end{tabular}

Figures are arranged in the order of electrophoretic patterns shown in Fig. 1. The average of $\mathrm{L} / \mathrm{K}$ ratios of the samples, including the above, prepared between August, 1990, and March, 1991 ( $\pm \mathrm{x}$ indicates the standard deviation): Extracts with $\mathrm{Mg}, 14 \pm 6$ (8 samples); Ammonium sulfate fractions, $88 \pm 26$ (7 samples); Gel-filtered, $145 \pm 63$ (4 samples). The supernatant of $28 \mathrm{~g}$ ammonium sulfate showed much lower $\mathrm{L} / \mathrm{K}$ ratios, e.g., those of the precipitates between $28 \mathrm{~g}$ and $32 \mathrm{~g}$ ranged from 1.5 to 22 ( 6 samples). The activities of preparations derived from frozen mince were significantly lower than those from fresh mince; the L-activity was more intensely affected so that the $\mathrm{L} / \mathrm{K}$ ratios were 30 to $70 \%$ lower than the above (detailed data not shown).

The first Mg extract had shown a distinct pattern of the $155 \mathrm{kDa}$ component, but up to the step of ammonium sulfate fractionation, a considerable amount of protein of smaller molecular weights, $18-40 \mathrm{kDa}$, was seen in the lower top portion of the gels (its actual amount exceeded $60 \%$ of total protein). Most of such small proteins were separated from $155 \mathrm{kDa}$ protein by gel-filtration. Caldesmon (indicated by an arrowhead) was the most frequent contaminant, especially in the cases where frozen mince was used. No means is available at present to eliminate once-contaminated caldesmon.

Discussion. As shown in the Results, the $\mathrm{L} / \mathrm{K}$ ratios of preparations exceeded 100 , reaching a maximum of 230 , i.e., more than 10 times that heretofore reported. ${ }^{1)}$ This means that an appropriate amount of $155 \mathrm{kDa}$ protein can activate actomyosin without any noticeable phosphorylation of MLC, confirming the early result that the contractile processes took place without phosphorylation of MLC. ${ }^{5)}$ We have thus virtually achieved separation of the actomyosin-activating activity from MLCK activity. In other words, the idea of "leiotonin" proposed in early days $^{6)}$ has now been realized.

We do not yet have a plausible explanation that could reconcile the present result with the widely accepted MLCK concept. It is conceivable, however, that $155 \mathrm{kDa}$ protein may have a dual function: it may assume its physiological role through the cooperation of L- and Kactivities. One possible way along this line is that phosphorylation would fortify the filamentous assemblies of smooth muscle myosin, which are very labile compared with skeletal myosin filaments. In other words, in our testing system, which is high in its $\mathrm{Mg}$ concentration and low in its ionic strength, myosin filaments are stabilized so that the effect of $\mathrm{K}$-activity is hardly seen, whereas those in the fiber models are very fragile and therefore require $\mathrm{K}$-activity. The most desirable tool at this stage is the desensitized fiber model, i.e., the model from which the active principle, MLCK, $155 \mathrm{kDa}$ protein or its equivalent, has been removed. This might be a key to solving the question raised above, although so far we have not seen any potential model for this.

\section{References}

1) Kuwayama, H., Suzuki, M., Koga, R., and Ebashi, S. (1988) J. Biochem. 104, 862-866.

2) Ebashi, S., and Kuwayama, H. (1994) Can. J. Physiol. Pharmacol. 72, 1377-1379.

3) Pires, E. M. V., and Perry, S. V. (1977) Biochem. J. 167, 137-146.

4) Ebashi, S., and Koga, R. (1981) Proc. Japan Acad. 64B, 98-101.

5) Ebashi, S., and Kuwayama, H. (1988) In Calcium Signal and Cell Response (eds. Yagi, K., and Miyazaki, T.). Japan Sci. Soc. Press, Tokyo/Springer-Verlag, Berlin, pp. 143-150.

6) Ebashi, S., Mikawa, T., Hirata, M., Toyo-oka, T., and Nonomura, Y. (1977) In Excitation-contraction coupling in smooth muscle (eds. Casteels, R., Godfraind, T., and Rüegg., J. C.). Elsevier North-Holland Biomedical Press, Amsterdam, pp. 325-334. 